\title{
ARTICLES
}

\section{Party Autonomy, Distributive Justice and the Conclusion of Contracts in the DCFR}

\author{
Horst EIDENMÜLLER*
}

Abstract: The rules on the conclusion of contracts are at the core of contract law. This article aims not only to describe these rules contained in Book II of the academic Draft Common Frame of Reference $\left(D C F R^{1}\right)$ but also to illustrate the underlying values and policies. The $D C F R$ severely restricts contractual freedom and pursues distributive aims. Unfortunately, it is certainly inefficient and often even impossible to achieve the latter goal through private law. The DCFR's provisions on non-discrimination, withdrawal rights as well as on contractual fairness in particular are critically examined against this background. These provisions address important problems, but they are not based on a convincing private law theory. The article suggests various improvements of the DCFR's rules to take party autonomy, and bence efficiency, more seriously.

Résumé: Les règles relatives à la conclusion des contrats sont le coeur du droit des contrats. Cet article vise non seulement à décrire ces règles contenues dans le livre II du Projet universitaire de Cadre Commun de Référence (PCCR), mais également à expliciter les valeurs et politiques sous-jacentes. Le PCCR restreint drastiquement la liberté contractuelle et poursuit des buts de redistribution. Malbeureusement, il est certainement inefficace et souvent même impossible d'atteindre ces objectifs à travers le droit privé. En particulier, les dispositions du PCCR sur la non-discrimination, les droits de retrait ou encore la justice contractuelle sont examinées d'un point de vue critique à cette aune. Ces dispositions soulèvent des problèmes importants, et elles ne sont pas fondées sur une théorie convaincante $d u$ droit privé. L'article suggère des améliorations diverses des règles $d u$ PCCR afin de prendre davantage au sérieux l'autonomie des parties et, partant, l'efficacité.

Kurzfassung: Die Normen zum Abschluss von Verträgen zäblen zum Kern des Vertragsrechts. Dieser Artikel beabsichtigt nicht nur, diese im Buch II des akademischen Draft Common Frame of Reference (DCFR) enthaltenen Regeln zu beschreiben, sondern auch, die zugrunde liegenden Werte und Grundsätze darzustellen. Das DCFR grenzt die Vertragsfreibeit erbeblich ein und verfolgt distributive Ziele. Leider ist es jedoch ineffizient und häufig sogar unmöglich, solche Ziele durch Privatrecht zu erreichen. Namentlich die Vorschriften des DCFR zu Nichtdiskriminierung, Widerrufsrechten und vertraglicher Fair-

* Professor of Private Law, German, European and International Company Law at the Ludwig Maximilian University, Munich (Research Professorship), and Fellow of the Institute for Advanced Study, Berlin (2008/2009).

1 C. von Bar / E. Clive / H. Schulte-Nölke / H. Beale / J. Herre / J. Huet / P. Schlechtriem / M. Storme / S. Swann / P. Varul / A. Veneziano / F. Zoll (eds), Principles, Definitions and Model Rules of European Private Law - Draft Common Frame of Reference (DCFR) - Interim Outline Edition (Munich: Sellier, 2008). 
ness werden unter diesem Blickwinkel kritisch untersucht. Diese Vorschriften betreffen zwar bedeutende Probleme, fußen jedoch auf keiner überzengenden Theorie des Privatrechts. Der Artikel schlägt verschiedene Verbesserungen zu den Normen des DCFR vor, um Privatautonomie und somit Effizienz stärker zum Durchbruch zu verbelfen.

The conclusion of contracts is prima facie regulated by rather 'technical' mechanisms. They comprise rules concerning the communication of contractual statements, the validity and interpretation of these statements as well as representation through agency. There are of course such technical rules in Book II of the DCFR. However, these have been supplemented by the Acquis Principles (ACQP) $)^{2}$ dealing with consumer protection. Most of the latter provisions go far beyond the simple mechanics of contract formation by making (or requiring a court to make) strong judgments on contractual fairness. They include not only extensive withdrawal rights, but particularly rules on non-discrimination and on a general fairness control of contracts. It is at least doubtful whether these rules are supported by persuasive lawmaking policies and whether they should be part of a private law codification or a body of private law rules.

The following article will critically examine the provisions regarding the conclusion of contracts in the academic DCFR. The DCFR's authors have provided an academic draft. I therefore take the liberty of criticising the draft as such. At the heart of my considerations lies the search for better law - not political utility, usability or feasibility. My main criticism is directed to the unreflective incorporation of the ACQP into the DCFR. ${ }^{3}$ Information duties I leave out, as they have been extensively examined elsewhere. ${ }^{4}$ After a brief overview of the content of Book II (I), I will discuss the defi-

2 Research Group on the Existing EC Private Law (Acquis Group), Principles of the Existing EC Contract Law (Acquis Principles) - Contract I: Pre-contractual Obligations, Conclusion of Contract, Unfair Terms (Munich, Sellier: 2007).

3 The project thereby fails to give effect to one of its core aims. See the Communication from the Commission to the European Parliament and the Council: European Contract Law and the revisions of the acquis: the way forward (11 October 2004): 'The research preparing the CFR will aim to identify best solutions, taking into account national contract laws (both case law and established practice), the EC acquis and relevant international instruments, particularly the UN Convention on Contracts for the International Sale of Goods of 1980.' Identifying 'best solutions' by 'taking into account' the $\mathrm{EC}$ acquis is not the same as its indiscriminative incorporation.

4 See F. Faust, 'Informationspflichten', in C. von Bar / R. Schulze / H. Schulte-Nölke (eds), Der akademische Entwurf für einen Gemeinsamen Referenzrabmen: Kontroversen und Perspektiven (Tübingen: Mohr Siebeck, 2008) 115. See also B. Fages, 'Pre-contractual Duties in the Draft Common Frame of Reference - What Relevance for the Negotiation of Commercial Contracts?" (2008) European Review of Contract Law 304, 308 et seq; S. Grundmann, 'The Structure of the DCFR - Which Approach for Today's Contract Law?' (2008) European Review of Contract Law 225, 238 et seq. 
nition of a contract offered by the DCFR (II). Subsequently, a couple of distinctive features of the rules on contract formation will be examined (III). The article then aims at identifying the general spirit underlying Book II of the DCFR (IV) and seeks to establish how efficiency and distributive justice are related to each other in the realm of private law $(\mathrm{V})$. On this basis, the rules of the DCFR relating to non-discrimination, withdrawal rights and the issue of the fairness of contracts will be examined (VI - VIII). The article concludes with a summary of its principal findings (IX).

\section{Content of Book II}

Book II is divided into nine chapters. Chapter 1 contains general provisions, Chapter 2 rules on non-discrimination, whereas marketing and pre-contractual duties are stipulated in Chapter 3. Chapter 4 covers the formation of a contract, whilst Chapter 5 identifies and sets out rights of withdrawal. Chapter 6 deals with representation, followed by grounds of invalidity (Chapter 7) and rules regarding the interpretation of contractual provisions (Chapter 8). Finally, Chapter 9 examines the contents and effects of contracts.

Book II contains various general provisions covering juridical acts, which from a German perspective would be allocated to the General Part ('Allgemeiner Teil') of a civil code. Although Book I of the academic DCFR also contains six general provisions, these deal with rather heterogeneous questions: they concern a wide scope of matters ranging from the DCFR rules' intended scope of application to their interpretation and further development as well as to the definitions in Appendix 1 and the provisions in Appendix 2 regarding computation of time and the meaning of 'signature' and similar expressions.

The main subject matter of Book II is contracts and other juridical acts, whilst Book III deals with obligations and corresponding rights. The duties contained therein not only comprise contractual, but also non-contractual duties. Book III thus very much resembles the general part of a law of obligations as it can be found, for example, in the German Civil Code ('Schuldrecht Allgemeiner Teil').

When analysing the structure of Book II, it is striking that the grounds of invalidity (Chapter 7) are dealt with prior to the provisions concerning interpretation (Chapter 8). This is not logical. Before asking whether a contract is invalid for infringing fundamental principles (Article II.-7:301) or mandatory rules (Article II.-7:302), its precise content must have been established. Therefore, the order of Chapters 7 and 8 ought to be reversed. 


\section{The Concept of a Contract in the DCFR}

At the very beginning of Book II, Article II.-1:101 provides the following definition of a contract:

'(1) A contract is an agreement which gives rise to, or is intended to give rise to, a binding legal relationship or which has, or is intended to have, some other legal effect. It is a bilateral or multilateral juridical act.

(2) A juridical act is any statement or agreement or declaration of intention, whether express or implied from conduct, which has or is intended to have legal effect as such. It may be unilateral, bilateral or multilateral.'

Offering a suitable definition for fundamental doctrinal categories such as a contract is a daunting task. This is clearly demonstrated by the definition in Article II.-1:101. Whereas on the one hand a contract is described as a bi- or multilateral juridical act (Article II.-1:101(1)), the term 'juridical act' is defined in Article II.-1:101(2). Hence, a contract is classified as a special form of juridical act, which remains the overarching concept. At the same time, the definition provided in Article II.-1:101(1) explicates a contract as an agreement. The latter, however, is apparently not specified. So what actually is an agreement? It definitely cannot be the same as a contract, as otherwise the definition provided in Article II.-1:101(1) would read as follows: 'A contract is a contract which ...'. Ultimately, a fundamental doctrinal category is defined by using another such category, for which a corresponding definition is missing.

Other aspects of the definition provided in Article II.-1:101(1), however, are problematic as well. For example, defining a contract as an agreement which gives rise to, or is intended to give rise to, a binding legal relationship, seems to imply that it is possible to conclude contracts without an intention to be legally bound. But does this really reflect the intentions of the drafters of the DCFR? Generally, it should be regarded as a rule of prudence not to provide definitions of fundamental doctrinal categories and leave the respective questions to jurisprudential analysis. Including such definitions in the wording of a legislative act probably creates more problems than it solves.

However, what definitely needs to be answered is the question whether the contractual provisions of Book II relate only to rights in personam or also to rights in rem as well as whether contracts governing rights in rem exist in the first place. Conceptually, the definition provided in Article II.-1:101 is not limited to contracts on rights in personam. One can easily understand the definition as encompassing contracts on rights in rem. This would have significant consequences, as various provisions of Book II concerning formation, interpretation and validity would extend to such contracts. On the other 
hand, there are a few special provisions which suggest that the provisions in this Book are limited to contracts governing rights in personam. For example, Article II.-7:212(3) setting out the effects of avoidance on the title to property refers to the provisions governing the transfer of property. Similarly, Article II.-7:303(2) states that in the case of contractual invalidity as a consequence of an infringement of fundamental principles or mandatory rules, the provisions relating to transfer of property apply. Hence, if Book II is intended to govern only contracts on rights in personam, this ought to be clarified in Article II.-1:101. The acquisition and loss of title to property would then come under a separate set of rules. Such provisions are not yet available, but are to be included in the final draft of the academic DCFR, as far as movables are concerned (Books VIII-X). ${ }^{5}$ Apparently, acquisition and loss of title to property under these provisions shall, in principle, depend on the validity of the contract governing the rights in personam. In that case, various exceptions to that principle are to be stipulated individually.

\section{Particularities of Contract Formation}

The DCFR provisions relating to contract formation in a more technical sense are to be found in Chapter 4 of Book II. These rules partially conform to the corresponding rules in existing civil codes such as the German BGB, but differ in some instances as well. In the following, I would like to elaborate on three of these differences: the legal treatment of an invitation to treat, the revocation of an offer and the receipt of an offer.

\section{The Treatment of an Invitation to Treat}

In German law, the public offer of a person to sell goods or render services at a certain price (textbook example: shop display) is not considered a binding offer according to Section 145 BGB but merely an invitation to treat. ${ }^{6}$ The issue is dealt with similarly by Article 14(2) CISG. Behind this rule lies the belief that it most closely reflects the interests of the parties involved. Perhaps the vendor's stock capacity does not allow for selling to every customer willing to buy. He may not even be willing to sell to every interested customer, especially when the vendee's creditworthiness is relevant for the transaction. Moreover, in the case of special offers it might not be in the vendor's

5 See C. von Bar / H. Beale / E. Clive / H. Schulte-Nölke, 'Introduction', in von Bar et al (eds), n 1 above, margin no 2, 39, 42.

6 So called 'invitatio ad offerendum'. See, eg, Kramer, in Münchener Kommentar zum $B G B\left(5^{\text {th }}\right.$ ed, Munich: C H Beck, 2006) Section 145 BGB margin no 7, 10. 
interest that one single customer purchases all or almost all of the available goods.

By contrast, the DCFR has incorporated a rule in Article II.-4:201(3) according to which offers made to the public at large are, under certain restrictions, to be categorised as valid offers. The provision reads as follows:

'A proposal to supply goods or services at stated prices made by a business in a public advertisement or a catalogue, or by a display of goods, is treated, unless the circumstances indicate otherwise, as an offer to sell or supply at that price until the stock of goods, or the business's capacity to supply the service, is exhausted.'

This provision does not give sufficient weight to the above-mentioned interests of a supplier of goods or services. It does not suffice to exempt suppliers from having to supply beyond their capacity as stated in the second half of the paragraph. As mentioned before, a supplier does not always have an interest in contracting with certain customers or, for instance, with one who wishes to purchase the entire stock of goods. Furthermore, the addition 'unless the circumstances indicate otherwise' does not offer any guidance and creates further uncertainty. This is a general characteristic of the DCFR's provisions. $^{7}$

\section{The Revocability of Offers}

A second interesting provision is found in the DCFR's rules on the revocability of offers in Article II.-4:202(1), which allows an offer to be revoked, '.. if the revocation reaches the offeree before the offeree has dispatched an acceptance or, in cases of acceptance by conduct, before the contract has been concluded.' However, according to Article II.-4:202(3) revocation is ineffective if the offer indicates that it is irrevocable, if it states a fixed time for its acceptance or if the offeree could reasonably rely on the offer as being irrevocable and has acted accordingly. In contrast, for example, Sections 130 para 1 sentence 1,145 BGB state that the offeror is bound by his offer as soon as it has been received by the offeree, unless he has expressly made clear that he does not wish to be bound.

Article II.-4:202(1) is essentially identical to Article 16(1) CISG. The provision is a modified version of the mailbox rule commonly found in Anglo-

7 See See H. Eidenmüller / F. Faust / H. Grigoleit / N. Jansen / G. Wagner / R. Zimmermann, 'The Common Frame of Reference for European Private Law - Policy Choices and Codification Problems' (2008) Oxford Journal of Legal Studies 659, 674 et seq. 
American jurisdictions. ${ }^{8}$ According to this rule, an offer has been validly accepted once the acceptance has been posted; it does not need to be received by the offeror. Correspondingly, as soon as the acceptance has been posted (and hence, after conclusion of the contract), revocation is no longer possible. Article II.-4:202(1) limits the mailbox rule to the aforementioned case. An offer is revocable until the acceptance has been posted. The contract, however, is concluded only when the acceptance reaches the offeror (Article II.-4:205(1)).

Considering the advantages and disadvantages of Article II.-402(1), the application of the mailbox rule seems justifiable. It provides an incentive for the offeree to decide quickly and therefore has an - economically beneficial - acceleration effect. In this respect, it is comparable to Section 147 para 2 BGB, but does not create legal uncertainty for the offeree, as he can conclude the contract by acceptance (whereas, according to Section 147 para 2 BGB an offer can only be accepted within a period of time in which the offeror, under normal circumstances, may reasonably expect to receive an acceptance.'). Article II.-4:202(3) contains appropriate limitations to revocability giving effect to the offeree's reasonable interests.

However, it should be recognised that the offeree may already have devoted resources to examine the offer prior to receiving the revocation, whereas the offeror has no way of knowing whether the offeree has already posted his acceptance (with the effect of the offer becoming irrevocable). In addition, the offeror may protect himself by including a revocability clause into the offer (in which case Article II.-4:202(1) is preempted). The decision made by the drafters of the DCFR to employ the mailbox rule in Article II.-4:202(1) may therefore be considered a compromise, justifiable in the light of the positive effects described above.

\section{Receipt of an Acceptance}

A final interesting feature of the DCFR's rules on contract formation regards the point in time at which a notice (in particular an acceptance) is received (among parties absent). In the German BGB, for example, Section 130 para 1 sentence 1 is interpreted as stating that receipt does not only require actual entrance into the addressee's physical sphere but also that, at that time, he can reasonably be expected to have taken notice. ${ }^{9}$ For instance, an acceptance posted into a company's mailbox on Friday evening is considered to

8 Adams v Lindsell (1818) 1 B \& Ald 681; Henthorn v Fraser (1892) 2 Ch 27; G.H. Treitel, The Law of Contract (12 ${ }^{\text {th }}$ ed, London: Thomson, Sweet \& Maxwell, 2007) 26 et seq.

9 Einsele, in Münchener Kommentar zum BGB ( $5^{\text {th }}$ ed, Munich: C H Beck, 2006) Section 130 BGB margin no 16 with further references. 
have been received no earlier than Monday morning. Article II.-4:205(1), however, stipulates that a contract is concluded at the point when the acceptance reaches the offeror. Again, this has an economically beneficial acceleration effect. The DCFR's rule can be justified by arguing that the offeror should organise his sphere in a way so as to enable prompt processing of incoming messages.

Apart from the provisions in the DCFR on contract formation discussed here, there are further rules on this rather technical subject matter. However, they seem to be of no particular importance and therefore shall not further be examined at this point. More important are the general characteristics of Book II, its 'spirit of the law', as well as the values and fundamental principles from which they can be derived. This focuses attention on a problem which will be discussed in the following, ie the DCFR's attempt to reach distributive justice by private law rules.

\section{Characteristic Features of Book II}

Book II is characterised by two predominant features, which are reflected in various provisions contained therein and which pervade the entire DCFR: the erosion of party autonomy and the expansion of judicial power. ${ }^{10}$

\section{Erosion of Party Autonomy}

Party autonomy is a fundamental principle not only of contract law, but of private law generally. It is the embodiment of a liberal conception of private law and ensures at the same time that resources are allocated efficiently. The DCFR's drafters acknowledge that 'freedom, in particular freedom of contract' is a principle which ought to be preserved and protected. ${ }^{11}$ However, this principle is only one among many others and an appreciation of party autonomy is only paid lip service, ${ }^{12}$ as many provisions of Book II demonstrate: parties to a contract are bound by general customary rules (Article II.-1:104(2)); the question whether parts of a contract remain in effect when other parts are invalid or ineffective is determined by an objective standard (Article II.-1:109); the principle of freedom of contract is limited by various non-discrimination rules (Article II.-2:101 et seq - see VI below); detailed pre-contractual information duties are imposed on both parties (Ar-

10 Eidenmüller / Faust / Grigoleit / Jansen / Wagner / Zimmermann, n 7 above, 676 et seq, 678 et seq.

11 Von Bar / Beale / Clive / Schulte-Nölke, n 5 above, margin no 22 et seq, 25 et seq.

12 On the plurality of values underlying the DCFR see Eidenmüller / Faust / Grigoleit / Jansen / Wagner / Zimmermann, n 7 above, 669 et seq. 
ticle II.-3:101 et seq); so-called merger or form requirements are ineffective in certain cases (Article II.-4:104(4), II.-4:105(2)); an invitation to treat is - as elaborated on above - sometimes conceived as being an offer (Article II.-4:201(3)); contracts can be avoided if one party has exploited the other party's lack of negotiation skills to gain an unfair advantage (Article II.-7:207(1)); contracts are void if they infringe fundamental principles of the Member States' jurisdictions (Article II.-7:301(a)); ${ }^{13}$ 'unjust' contractual clauses are subject to judicial scrutiny, in the case of b2c-contracts possibly even when they have been negotiated individually (Article II.-9:401 et seqsee below VIII).

Some of the rules listed above may be more 'threatening' to party autonomy than others, whilst some may at least partially be justifiable also on a basis of a liberal conception of private law. It is the sheer number of provisions restricting contractual freedom that is most troublesome. This impression is reinforced by the fact that even the provision entitled 'Party autonomy', Article II.-1:102(1), curtails party autonomy from the outset, as the principle is subject to the rules on good faith and fair dealing.

The fact that Article II.-1:102(2) enables parties to a contract to depart from any of the following rules thereto does not do much to strengthen the principle of party autonomy. Parties can (obviously) only make use of this provision 'except as otherwise provided', which clearly means: mandatory provisions cannot be excluded. What actually counts as mandatory law needs to be determined by interpretation if not otherwise specified. Of the provisions mentioned above, only Article II.-1:104(2) and perhaps Article II.-1:109 are non-mandatory. Furthermore, the possibility of contracting around trade usages (Article II.-1:104(2)) does not help in individual cases in which such usages have already been influential in the pre-contractual stage, as in cases in which it is disputed whether a contract has been formed in the first place.

\section{Expansion of Judicial Power}

The second predominant characteristic of Book II (and of the DCFR in general) is an expansion of the power of those who ultimately would have to apply the Book's rules, ie the judges. This characteristic is reflected in a mul-

13 The scope of this provision depends on whether not only EC-wide acknowledged principles can lead to the invalidity of a contract but also those originating (merely) in single Member States' jurisdictions. The text of the provision allows for the latter interpretation, which would lead to a multiplication of grounds for invalidity. See insofar also W. Ernst, 'Der "Common Frame of Reference” aus juristischer Sicht' (2008) Archiv für die civilistische Praxis 248, 270. 
titude of provisions. Courts would have to decide in individual cases whether unequal treatment can be justified by a legitimate aim and whether the means used to achieve that aim are appropriate and necessary (Article II.-2:103). They would also have to decide on the extent of remedies for unequal treatment (Article II.-2:104(2)), identify linked contracts (Article II.-5:106(2)), decide whether a conflict of interest arises when representatives are involved (Article II.-6:109), state whether the requirements for avoidance of a contract for mistake subsist and determine the legal consequences (Article II.-7:201 and II.-7:203), ${ }^{14}$ adapt contracts to avoid unfair exploitation (Article II.-7:207(2) and (3)), determine the consequences of violation of mandatory law (Article II.-7:302(2) and (3)) as well as imply an additional term to provide for a matter which the parties have not foreseen or provided for (Article II.-9:101(2)).

Whether judicial power is problematic with respect to legal certainty and foreseeability depends on how much 'binding force' is exerted by a common legal culture and methodology in individual cases. Considering that there is a vast range of legal traditions with regard to both substance and methodology in the EU's Member States, and keeping in mind the DCFR's pluralistic and heterogeneous value basis,${ }^{15}$ one is easily placed in doubt. There is a risk that private transactions would be moulded by those who apply the DCFR rules and implement their individual and special conceptions of fairness and justice.

Why is it that the academic DCFR regards the preservation of party autonomy as being one aim among many others whilst issuing a carte blanche to courts allowing them to shape the law, and hence private transactions, almost at their will? It is possible that the drafters of the DCFR have been led by the idea that private law provisions shall and will serve a multitude of different aims, if necessary also with the help of court rulings. Among these other aims is, in particular, distributive justice.

14 On this see H. Beale, 'The Draft Common Frame of Reference: Mistake and Duties of Disclosure' (2008) European Review of Contract Law 317, 325 et seq.

15 See Eidenmüller / Faust / Grigoleit / Jansen / Wagner / Zimmermann, n 7 above, 669 et seq. See also J.M. Smits, 'The Draft-Common Frame of Reference, Methodological Nationalism and the Way Forward' (2008) European Review of Contract Law 270, 278: 'Little help is available from an inventory of the "core aims of European private law" as long as the exact relationship between these aims is not made explicit." 


\section{Efficiency and Distributive Justice}

In this context, the introduction to the academic DCFR comes to the point quite straightforwardly. Of the many central aims and values underlying the DCFR, justice, solidarity and social responsibility are named first. ${ }^{16}$ As to justice it says: 'The DCFR is less concerned with issues of 'distributive justice', but sometimes distributive or 'welfarist' concerns may also be reflected in the DCFR .... ${ }^{17}$ According to its drafters, the DCFR is primarily aimed at corrective justice (in the Aristotelian sense), however not without 'at times' also trying to achieve distributive justice as well. One may ask whether the latter objective is indeed aimed at only 'at times' - my impression is rather that distributive justice is an overall aim pursued quite systematically. Be that as it may: it would have been better for the DCFR to not even try to achieve distributive purposes by the means of private law. On the one hand, redistribution by private law is always less efficient than redistribution by social and tax law, while on the other hand it is virtually impossible to attain when it comes to contract law. ${ }^{18}$

\section{Inefficiency of Redistribution by Private Law}

Redistributive measures always come with a loss of value due to the distortion of the comparative appeal of work and leisure. An income tax lowers the costs of leisure (lower opportunity costs) and increases the costs of work you work less if, for every Euro earned, you take home only 60 Cents (instead of the one Euro). In this respect, redistribution always leads to a loss of efficiency: the beneficiary gets less than was taken from the burdened party. To put it metaphorically: the water is carried in a bucket, but the bucket has holes and water is lost on the way. This loss of efficiency is significant. For the US, eg, it is estimated at 25 percent of the total redistribution volume. $^{19}$

Aiming for the same volume of redistribution as through taxation by private law rules will lead to the same loss of efficiency as described above. However, typically there is an additional loss of efficiency. When trying to use the rules of private law to establish distributive justice, those rules will regularly not

16 See von Bar / Beale / Clive / Schulte-Nölke, n 5 above, margin no 22.

17 See von Bar / Beale / Clive / Schulte-Nölke, n 5 above, margin no 24.

18 It is telling that in an article which criticises the DCFR for being too liberal (!), these considerations are not even mentioned once: M.W. Hesselink, 'Common Frame of Reference \& Social Justice’ (2008) European Review of Contract Law 248.

19 See H. Eidenmüller, Effizienz als Rechtsprinzip: Möglichkeiten und Grenzen der ökonomischen Analyse des Rechts ( $3^{\text {rd }}$ ed, Tübingen: Mohr Siebeck, 2005) 289. 
serve their purpose of setting efficient incentives for private transactions. ${ }^{20}$ For example, if the wealth of the injuring party were taken into account when determining the amount of compensation due in a tort case ('wealth surcharge'), this would create the same type of inefficiency as a redistributive tax. In addition, however, 'rich' tortfeasors would be led to apply higher standards of precaution than would be economically justified. Redistribution by private law is therefore always less efficient than redistribution by social and tax law.

\section{Impossibility of Redistribution by Contract Law}

Another problem is that redistribution cannot, or at least cannot systematically, be established by contract law. If, for example, compulsory obligations are imposed on a provider of goods or services, they will lead to higher costs. These costs will invariably be reflected in the price of certain goods and services and will therefore be paid by those who were originally supposed to benefit from the compulsory terms. Think, for instance, of a legally required standard of equipment for rented housing the purpose of which is to satisfy tenants. Measuring the welfare of all parties involved by both consumers' and producers' surplus shows that only in quite extraordinary cases higher costs (by mandatory legal provisions) lead to an increase in total consumers' and a decrease in total producers' surplus. A low elasticity of supply as opposed to a high elasticity of demand in the marginal area is required to obtain such a result. ${ }^{21}$ Except for these extraordinary circumstances, the intended beneficiary always has to pay for the 'legal benefaction' which was supposed to be 'free of charge' for him.

Even if a redistribution of rents in favour of certain beneficiaries is possible in single instances, it is impossible to realise it in a systematic way. Contrary to public transfer payments, not all people in need are being helped. The benefit depends on an accidental event, namely the conclusion of a particular contract. Not every intended beneficiary of redistribution will, for example, rent an apartment. Moreover, the position of a particular party to a contract, for example as a consumer, tenant etc, is insufficient evidence for social need-

20 This argument was developed by S. Shavell, 'A Note on Efficiency vs. Distributional Equity in Legal Rulemaking: Should Distributional Equity Matter Given Optimal Income Taxation?' (1981) 71 American Economic Review: Papers and Proceedings 414; L. Kaplow / S. Shavell, 'Why the Legal System is Less Efficient than the Income Tax in Redistributing Income' (1994) 23 The Journal of Legal Studies 667; Eidenmüller, n 19 above, 289 et seq, 291 et seq.

21 See D. Kennedy, 'Distributive and Paternalist Motives in Contract and Tort Law, with Special Reference to Compulsory Terms and Unequal Bargaining Power' (1982) 41 Maryland Law Review 563, 655 et seq; Eidenmüller, n 19 above, 298 et seq. 
iness. It may be that tenants of apartments tend to be needy - but this does not apply to all of them. A rule of private law requiring a mandatory standard of equipment for housing would equally benefit very wealthy tenants. Systematic redistribution is thereby impossible. ${ }^{22}$

In any case, one has to keep in mind that attempts at redistribution by rules of private law will almost always lead to increases in costs and that marginal consumers (the 'poorest of the poor') will thereby disappear from the market (they simply cannot afford the 'legally enhanced' product any longer and are 'priced out' of the market). Furthermore, this leads to a cross-subsidisation between particular beneficiaries (usually consumers): the consumers whose personal benefit by the 'legally enhanced' product is comparatively low pay for the higher benefit of those who have more use for the enhancement. ${ }^{23}$

Therefore, there is good reason to conclude that redistribution is not a reasonable aim of legal policies in contract law. The opposite, however, is true for a conception of private law which aims directly at establishing party autonomy to the fullest extent possible and, thereby, at an efficient allocation of resources as well. Economic efficiency is a reasonable objective of policymaking in the field of private law. The primacy of this objective does not imply that there should not be any mandatory rules at all. Quite to the contrary: economic theory has a lot to say with respect to justifying mandatory legal rules. However, the DCFR's model rules of Book II do not reflect economic thinking at all. I should like to elaborate this now with respect to the rules on non-discrimination, withdrawal rights and contractual fairness.

\section{Rules on Non-Discrimination}

The DCFR's rules on non-discrimination (Article II.-2:101 et seq) in particular illustrate clearly the counterproductive effects that occur when social or distributive aims are pursued by mandatory rules on contracts. Article II.-2:101 accords every person a right against discrimination on the grounds of sex, ethnic or racial origin, in relation to a contract or other juridical act the object of which is to provide access to, or supply, goods or services which are available to the public. Violating this right leads, according to Article II.-2:104(1), to liability for damage on the side of the violator and - by reference to Chapter 3 of Book III - where applicable also to an obligation to contract (Article III.-3:302). The remedy granted according to Article II.-2:104(2) must be proportionate to the injury or anticipated injury. The

22 See Eidenmüller, n 19 above, 303 et seq.

23 See also G. Wagner, 'Die soziale Frage und der Gemeinsame Referenzrahmen' (2007) Zeitschrift für Europäisches Privatrecht 180, 208 et seq. 
second clause of this provision contains the remarkable statement: '...the dissuasive effect of remedies may be taken into account.' This means, plainly speaking, that the court ruling on such a case shall be allowed to decide on punitive damages in order for the desired deterrent effect to be achieved.

Contrary to the drafters' view, these rules will largely fail to prevent or at least reduce discrimination based on the grounds mentioned. Their immediate effect is that persons or institutions who - for whichever reasons - want to discriminate will be looking for unsuspicious 'alternative grounds' to reach their goal otherwise. Someone who does not want to hire non-white employees, for example, will place special emphasis on schools and universities a candidate has visited, etc. Moreover, Article II.-2:103 allows discrimination by way of exception, if it is justified by a legitimate aim and the means used are both appropriate and necessary. The potential for disagreement on such issues is obvious. Imagine an elderly woman who, on principle, lets a room only to younger women simply because she finds their company pleasant. Would this be a justified discrimination by a potential lessor according to the said article? All in all, the effects described above lead to higher transaction costs (search for unsuspicious 'alternative grounds', conflicts regarding the legitimacy of a goal and the proportionality of the means, etc). According to simple laws of microeconomics, this has a series of counterproductive results: the prices for goods and services offered on the affected markets will rise, the amount in demand will decline, and above all, marginal demanders (typically those with the lowest purchasing power and therefore from a social perspective those most in need of protection) are 'priced out' of the market they cannot afford the desired good or the needed service at the new market price any more. This result certainly does not correspond with the purpose of Article II.-2:101 et seq.

In order to prevent misunderstandings: this is not about the question whether discrimination on the grounds stated in Article II-2:101 (or others) should be politically disapproved of or not. The issue at stake is rather the less controversial question whether rules of private law are an efficient protective mechanism against discrimination. They are not: they have counterproductive effects, particularly by squeezing out of the market those people or groups of people who are most in need of protection. In order to reduce undesirable discrimination in the field of private law effectively, one should choose an approach that does not influence the process of price formation in markets. A sensible approach would improve the situation of minorities by a bundle of measures. This bundle can and should contain, above all, measures that promote education, but also direct allowances such as social transfer payments. These measures would support beneficiaries in their role as market participants while at the same time reducing the risk of dis- 
crimination by others by making it economically (even) less reasonable. The opportunity costs of discrimination would rise. ${ }^{24}$

\section{Rights of Withdrawal}

The belief in (allegedly efficient) protective mechanisms on behalf of 'weak' parties can be observed not only in the rules on non-discrimination. The extensive withdrawal rights in Chapter 5 of Book II (Article II.-5:101 et seq) also reflect a lack of grounding. Given that the drafters have not sufficiently realised the purpose and effectiveness of rights of withdrawal, their proposals suffer from fundamental flaws.

\section{Purpose and Effectiveness of Rights of Withdrawal}

The purpose of rights of withdrawal is to prevent the conclusion of contracts which are not conforming with the parties' preferences and thus inefficient. ${ }^{25}$ The conclusion of such contracts can be due to both exogenous and endogenous disturbances in the parties' decision-making process. With regard to exogenous disturbances, it must be carefully examined under which conditions and circumstances someone can be held to acquire goods or services he has no reasonable use for, at least not at the price agreed upon. This will be the case particularly in situations when someone is taken entirely by surprise (eg in doorstep transactions). It is harder to argue that the same is true for long-distance transactions. It is usually suggested that a right of withdrawal in such cases is justified based on the fact that the buyer has no opportunity to examine the purchased goods in advance. ${ }^{26}$ This consideration, however, does not justify a general right of withdrawal from long-distance transactions. It is plausible merely for certain goods, insofar as their quality can indeed be examined only upon receiving them. The case is different for standardised goods (eg pens of a certain brand) or goods whose quality cannot be conclusively determined even when purchasing

24 This is only seemingly at odds with G. Becker, The Economics of Discrimination (2 ${ }^{\text {nd }}$ ed, Chicago: University of Chicago Press, 1971) 110 et seq, according to whom discrimination against the nonwhite population and their education are positively related. The explanation provided therefore ('Whites in lower occupations may greatly discriminate against them because they have a relatively large amount of authority and decision-making powers', ibidem at 155) was time-dependent (applicable to the US in the $40 \mathrm{~s}$ and $50 \mathrm{~s}$ of the last century) and is now out-dated.

25 See H. Eidenmüller, 'Exerting Pressure in Contractual Negotiations' (2007) 3 European Review of Contract Law 21, 38 et seq.

26 Wendehorst, in Münchener Kommentar zum BGB (5 $5^{\text {th }}$ ed, Munich: C H Beck, 2007) Preliminary note to Section $312 \mathrm{~b}$ et seq BGB margin no 4 . 
them in a shop, since it shows only in the course of being used (eg software programmes).

Even more difficulties than with exogenous disturbances in the process of preference formation arise when assessing the legitimacy of rights of withdrawal based on endogenous effects. At first sight, a right of withdrawal seems to be justified in the case of particularly problematic (complex) contracts, as it is to be expected that a considerable amount of time and effort are needed in order to figure out whether the benefits of such a contract outweigh its costs. However, this can well be done prior to the conclusion of a contract, ie before 'walking into a trap'. Besides, it is extremely difficult to draw up a sufficiently clear typology of such complex contracts by which they can be distinguished from others, which do not come with a right of withdrawal. A withdrawal right based on endogenous disturbances in the decision-making process for all complex contracts eventually leads into general legal paternalism. ${ }^{27}$

The problem is not only that it is difficult to precisely define legal situations in which there are good reasons for granting a right of withdrawal, since someone has entered into an inefficient contract (not conforming with his preferences). In addition, it is questionable how effectively rights of withdrawal serve as protective measures. In practice, only about one to six percent of existing rights of withdrawal are actually exercised. ${ }^{28}$ There are various reasons for this: it might be the case that the contracts concluded are mostly efficient, which is why there is no economic incentive to withdraw. However, it might also be that other disturbances in the process of rational decisionmaking lead to the omission of a withdrawal, even though a contract is inefficient. ${ }^{29}$ Findings in the field of cognitive psychology show that we irrationally overrate goods we possess compared to those we do not possess ('endowment effect'). This may result in the situation that we are reluctant to return a certain good, even though we did not actually want to purchase it at the price agreed upon. Moreover, there is sufficient empirical evidence that

27 Concerning the philosophical problems related to paternalism see Eidenmüller, n 19 above, 358 et seq.

28 Market study regarding doorstep selling of the Office of Fair Trading, May 2004, Annex L, 50. The study can be found at http://www.oft.gov.uk/advice_and_resources/ resource_base/market-studies/completed/doorstep-selling\#below (last visited 17 November 2008); BT-Drucksache 10/2876 of 15 February 1985, 8; G. Magoulas / A. Schwartze, 'Das Gesetz über den Widerruf von Haustürgeschäften und ähnlichen Geschäften: Eine rechtliche und ökonomische Analyse' (1986) Juristische Arbeitsblätter 225, 230.

29 See in the following H. Eidenmüller, 'Der homo oeconomicus und das Schuldrecht: Herausforderungen durch Behavioral Law and Economics' (2005) Juristenzeitung 216, 221. 
we try to reduce cognitive dissonances. Having just purchased a good, we do not want to have to revise our decision immediately afterwards (and thereby act inconsistently with our own prior behaviour). In the light of these effects, it should be considered whether other instruments might be more effective in protecting from contracts not conforming to our preferences than rights of withdrawal. Instead of withdrawal, which requires a certain activity of the entitled party in order to terminate the unwanted contract, one could think of, for instance, the requirement of a 'confirmation of a contract': a contract would become ultimately effective only if confirmed by the beneficiary of the legal rule within the course of a certain period of time and in a certain form. ${ }^{30}$

To conclude: rights of withdrawal as protective measures against contracts not conforming to a party's preferences are sensible only in clearly defined situations. In addition, their effectiveness as protective measures is doubtful. This should be reason enough to consider alternatives.

\section{Rights of Withdrawal in the DCFR}

The conception of rights of withdrawal in the DCFR, however, does not take these findings into account. After a series of rules on the exercise and the effects of a right of withdrawal (Article II.-5:101 et seq), Article II.-5:201 and Article II.-5:202 establish two 'particular rights of withdrawal'. According to them, a consumer can withdraw from any contract related to a b2c-transaction if he has given his consent to the contract away from the business premises (Article II.-5:201(1)). Moreover, the consumer in a b2c-transaction has a right of withdrawal from all timeshare contracts on immovable property (Article II.-5:202(1)).

As discussed above, the fact that a consumer's consent to a contract was given away from the business premises of the other party is an inadequate criterion for identifying situations in which inefficient contracts, ie contracts not conforming to the consumer's preferences, are typically concluded. The only argument to support such position is the consideration that away from business premises one allegedly does not expect to be drawn into negotiations potentially leading to a contract. ${ }^{31}$ While this may be true occasionally, it certainly is not true generally. Moreover, the really important question is where more intensive manipulation is to be expected. There is no doubt that manipulative sales practices are exercised also on business premises. Further, someone who is not exposed to the 'sales machinery' installed on such premises and is also

30 See Eidenmüller, n 29 above, 222.

31 Møgelvang-Hansen / E. Terryn / R. Schulze, in Research Group on the Existing EC Private Law (Acquis Group), n 2 above, Art 5:201 margin no 3. 
able to escape from any 'treatment' quickly should more likely come to a rational decision than he who finds himself under the influence of manipulative sales practices in a shop.

Thus, there is no reason for a general right of withdrawal for contracts to which a consumer has consented away from business premises. The drafters of the DCFR eventually acknowledge this, as they are compelled to restrict the general rule of a right of withdrawal in Article II.-5:201(1) by an extensive series of exceptions in Article II.-5:201(2) to (4). However, this list is unconvincing as well. Why, for example, should it be impossible to withdraw from an order of canned goods by phone (Article II.-5:201(2)(d)), whereas the same would be possible regarding the order of a pen concluded via the internet? Why should there be no right of withdrawal from the order of a scientific journal by phone (Article II.-5:201(3)(e)), but one from the online order of a book? Overall, the distinctions regarding rights of withdrawal are not convincing.

The same criticism is to be levelled against Article II.-5:202 granting a right of withdrawal for timeshare contracts. As discussed above, the complexity of a contract as evidence of endogenous disturbances in the decision-making process cannot sensibly serve as a criterion for the legitimacy of a right of withdrawal. In addition, it is unclear why of all things only timeshare contracts should justify a right of withdrawal. Such contracts seem to be a rather bad example. In most cases the purchaser of such a right realises existing problems only when first using the property. The withdrawal period of Article II.-5:103, however, has ended by then.

In light of these considerations, a fundamental revision of the rules on rights of withdrawal in Chapter 5 is highly recommended. A (radical) solution could be to let the market practice regarding the conclusion of contracts decide on the efficiency of rights of withdrawal. Technically, this could be done by changing Article II.-5:101 et seq into non-mandatory provisions (for now, they are mandatory, cf Article II.-5:101(2)). In many lines of business, customers are granted voluntary rights of withdrawal ('conversion rights'). ${ }^{32}$

32 See, eg, the list of businesses granting rights of withdrawal by the Austrian Workers' Chamber: http://help.orf.at/dateien/3451_Umtauschrecht1[1].pdf (last visited 17 November 2008). According to a spokesman of the retail sector in Hamburg, withdrawal is possible from almost all contracts, at least after the Christmas season: http:// www.abendblatt.de/daten/2005/12/28/517519.html (last visited 17 November 2008). This corresponds with the practice of businesses in several branches who on their web pages grant a non-mandatory right of withdrawal: http://www.praktiker.de/servlet/ $\mathrm{PB} / \mathrm{menu} / 1038726 /$ index.html; http://www.ikea.com/ms/de_DE/customer_service/ ikea_services/ikea_services.html; http://www.amazon.de/gp/css/returns/homepage. $\mathrm{html} / \mathrm{ref}=$ hy_f_4 (grants a right to withdraw within a period of 30 days); http:// 
These will certainly be cases in which the benefit of granting such a right is, for the business, higher than the costs it causes. One cannot expect a similar voluntary right of withdrawal to be granted, for example, in doorstep selling. In case of genuine exogenous disturbances of preferences, the general practice of concluding contracts cannot be relied upon as far as efficiency is concerned. The result, rather, is a market failure.

Therefore, a revision of Chapter 5 should retain the mandatory character of rights of withdrawal. The prerequisites for a withdrawal, however, must be defined more narrowly and precisely in order to identify situations in which it is very likely that exogenous or endogenous disturbances in the decisionmaking process lead to inefficient contracts. Apart from that, the mechanisms of 'rights of withdrawal' must be reconsidered. For the reasons discussed above, it might be worth substituting 'rights of withdrawal' by 'obligations to confirm' as prerequisites for the validity of those (few) contracts for which a 'right of withdrawal' is justified.

\section{Rules on Contractual Fairness}

Various causes may lead to the conclusion of inefficient contracts. One of them is the exogenous or endogenous disturbance of preferences at the time of conclusion discussed above. Yet inefficiencies may also result from the fact that certain parts or terms of a contract are readily (without scrutiny) accepted by one party and thus lie beyond the ambit of market control. This problem notoriously arises with regard to standard terms. There seems to be consensus by now that inappropriate terms are not the result of greater bargaining power of the party using this instrument in negotiations. Otherwise it would be hard to explain why a substantive restriction might be sensible even in b2b-relations, that is to the benefit of a business that at first sight seems to be the stronger party. Inadequate contractual clauses result rather from the 'rational ignorance' of the other party for whom it is not worth checking the legal 'quality' of certain terms and make his decision depend on it. Conversely, there is no incentive for the party supplying the terms of a contract to offer terms of high 'quality' - as the price the other party is willing to pay does thereby not increase. This may lead to a 'Market for Lemons', ie: the lowest 'quality of terms' will prevail..$^{33}$

www.mediamarkt.de/service/; http://www.karstadt.de/kategorieAnzeigen.do?kid= 879018 (last visited 17 November 2008).

33 The negative impact of asymmetrical information on the functioning of markets was discussed for the first time in depth by G. Akerlof, "The Market for "Lemons": Quality Uncertainty and the Market Mechanism' (1970) 84 Quarterly Journal of Economics 488-500. His argument has been extended to the market of general contract terms by M. Adams, 'Ökonomische Analyse des Gesetzes zur Regelung des Rechts der All- 


\section{Terms not Individually Negotiated}

The DCFR offers a very wide concept of 'not individually negotiated' terms. Article II.-9:403(1) states that a term supplied by one party is not individually negotiated if the other party '...has not been able to influence its content, in particular because it has been drafted in advance, whether or not as part of standard terms. ${ }^{34}$ This rule is followed by a rule on the burden of proof in Article II.-9:403(4), according to which the business in a b2c-contract bears the burden of proving that a term supplied by the business has been individually negotiated. Taken together, these two rules imply that terms supplied by a business which were not altered in the negotiation process would practically always be considered to be not individually negotiated.

However, this is a deficient view on negotiations as such, which does not correspond to the logic of the control of standard terms described above. The point is not whether a certain term was altered or not. The crucial point is, rather, whether a term was relevant for the process of 'give and take', even if it remained unchanged in the end. In the bargaining process it is common for one party to accept a certain term (thus to grant a concession) in order to be granted a concession from the other side in return. A consumer may, for example, consciously 'pass over' a term containing a restriction of liability when negotiating a contract with a business, since he will thereby be able to purchase the desired goods - after the negotiations - at a lower price in exchange. In this case, there is no 'rational ignorance' regarding the term concerned, and a substantive review of terms would be unjustified. The articles of the DCFR cited above should take this into account. They should stipulate that a term is not individually negotiated only if it was not even potentially subject to negotiation and thus was of no relevance for the balance of particular contractual obligations, performances and risks assumed in the negotiation process. If a standard term supplied by a business survived the negotiation process unchanged in a b2c-transaction, the burden of proving the

gemeinen Geschäftsbedingungen (AGB-Gesetz)', in M. Neumann (ed), Ansprüche, Eigentums- und Verfügungsrechte - Schriften des Vereins für Socialpolitik (Berlin: Duncker \& Humblot, 1984) 655-680. In academic commentaries, this position was also assumed early on by H. Kötz, in Münchener Kommentar zum $B G B\left(3^{\text {rd }}\right.$ ed, Munich: C H Beck, 1993) preliminary notes to AGBG margin no 3. It is now widely held in the scholarly literature, such as by J. Basedow, in Münchener Kommentar zum $B G B\left(5^{\text {th }}\right.$ ed, Munich: C H Beck, 2007), preliminary note to Sections 305 et seq BGB margin no 5 .

34 The usage of the terms 'not individually negotiated' and 'standard terms' in Art II.-9:403 is contradictory. Art II.-9:403(1), Art II.-9:403(3) and Art II.-9:403(4) are based on the conception that in principle even 'standard terms' can be agreed upon individually. However, this is contrary to the definition of 'standard terms' found in Appendix 1 according to which standard terms are never individually negotiated. 
individual negotiation of the term in the sense just described should be put on the business.

\section{Scrutiny of Individually Negotiated Terms}

The biggest problem with Article II.-9:401 et seq, however, is to be found elsewhere. Article II.-9:404 prescribes a fairness check for b2c-contracts possibly even for terms that were individually negotiated. The square brackets in the text show that a decision on this matter has not yet been made, but is to be expected for the final version of the DCFR. In the event that a fairness check should be available even for individually negotiated terms, the long list of (refutably) presumed unfair terms in Article II.-9:411 would be applicable as well in this context.

Indeed, there is no good reason for a general fairness check of individually negotiated terms. Such control would significantly curtail if not practically eliminate party autonomy in b2c-relations. Every contract by a consumer would be open to comprehensive and substantive judicial examination. In addition, the DCFR - as illustrated above - contains a series of other rules which erode party autonomy and introduce substantive elements of fairness control into private law. The courts, for example, would already have the opportunity to intervene based on a party's lack of experience in negotiating (Article II.-7:207); apart from that, the entirety of mandatory laws on consumer protection would, of course, continue to apply. All these existing and questionable protective measures would be made superfluous if Article II.-9:404 should indeed allow a fairness check of individually negotiated terms. Hope remains that this plan will be abandoned.

\section{Splitting up the Fairness Check}

Article II.-9:404 to II.-9:406 establish three different kinds of fairness checks for $\mathrm{b} 2 \mathrm{c}-, \mathrm{c} 2 \mathrm{c}-$, and b2b-contracts respectively. Regarding b2c-contracts the test is whether a term ' ... significantly disadvantages the consumer, contrary to good faith and fair dealing.' A similar standard shall apply to c2c-contracts. The criteria for potential unfairness in b2b-contracts, however, are met when a term '.. grossly deviates from good commercial practice, contrary to good faith and fair dealing.' This splitting of the fairness check, depending on whether a consumer is disadvantaged or not, is unfortunate. ${ }^{35}$ Also, mere deviations from good commercial practice are not as relevant as significant disadvantages in the sense of an unbalanced assumption of

35 See also the criticism by T. Pfeiffer, 'Non-Negotiated Terms', in R. Schulze (ed), Common Frame of Reference and Existing EC Contract Law (Munich: Sellier, 2008) 177, 179. 
risks. It would be better (and simpler) if the DCFR had confined itself to determine that not individually negotiated terms which inappropriately disadvantage the other party are unfair and thus in any case not binding on the disadvantaged party (on the effects of unfair terms cf Article II.-9:409).

\section{Summary}

Book II of the academic DCFR goes far beyond technical rules on the formation of a contract. It is characterised by several sets of provisions which severely restrict the parties' contractual freedom and thereby erode party autonomy. The most important results of the above analysis can be summarised as follows:

1. The definition of a contract in Book II is dispensable. However, the scope of the rules proposed in the Book should be clarified. In particular, it must be specified whether the rules apply to contracts in rem (if such contracts are recognised at all).

2. The DCFR rules on the formation of a contract depart from existing European codes such as the German BGB in some respects. These modifications are in part well justified and in this sense a progress.

3. Apart from these rather technical rules, Book II is essentially characterised by an erosion of party autonomy and an expansion of judicial power regarding the examination of contracts.

4. The erosion of party autonomy in Book II is based on the assumption that rules of private law can be used in order to implement a great variety of aims, including in particular redistributive ones. Redistribution, however, is not a sensible goal in contract law.

5. Rules of private law aimed at non-discrimination are mostly ineffective. They lead to counterproductive results and, to a large extent, miss their primary purpose. The interests of minorities should instead be advanced by public support and protective measures which do not influence the process of price formation on markets.

6. Rights of withdrawal as a means to prevent inefficient contracts (ie contracts not conforming to preferences) are sensible only in clearly defined situations. Moreover, the protective effects of such rights is questionable. The DCFR rules on rights of withdrawal are not very well thought through.

7. A substantive fairness review of a contract should be conducted only with respect to not individually negotiated terms. There is no substantive reason for policing individually negotiated terms. However, such a check is envis- 
aged by the DCFR. Insofar as the question is whether a term was individually negotiated or not, it is irrelevant whether it was actually altered. The crucial point is the negotiation process of 'give and take'. The DCFR does not take this into account. 